The effect of pressure on pseudor ot axane for mat i on by using the sl i ppi ng method

\begin{tabular}{|c|c|}
\hline 著者 & $\begin{array}{l}\text { TOKUNAGA Yuj i, WAKAMATSU Nanae, OHBAYASH } \\
\text { Aki hi ro, AKASAKA Koi chi ro, SAEKI Susum, } \\
\text { H SADA Kenj i, GODA Tat suhi ro, SH MOMURA Youj i }\end{array}$ \\
\hline $\begin{array}{l}\text { j our nal or } \\
\text { publ i cat i on titl e }\end{array}$ & Tet r ahedr on Let ter $\mathrm{s}$ \\
\hline vol une & 47 \\
\hline number & 16 \\
\hline page $r$ ange & $2679-2682$ \\
\hline year & $2006-04-17$ \\
\hline URL & ht t p: //hdl . handl e. net /10098/1913 \\
\hline
\end{tabular}


Graphical Abstract

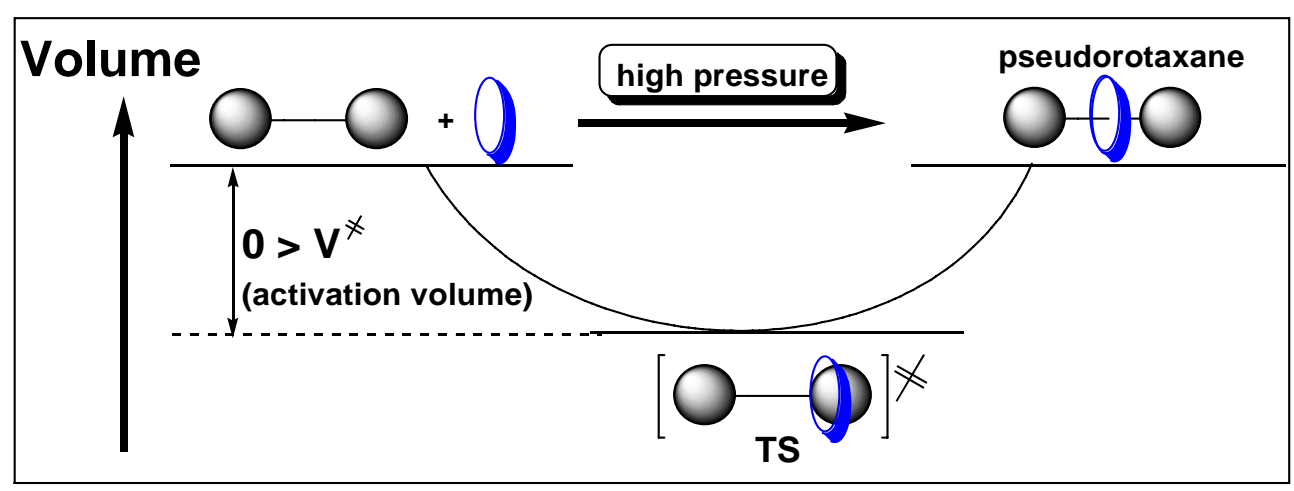




\title{
The effect of pressure on pseudorotaxane formation by using the slipping method
}

\author{
Yuji Tokunaga,* ${ }^{\mathrm{a}}$ Nanae Wakamatsu, ${ }^{\mathrm{a}}$ Akihiro Ohbayashi, ${ }^{a}$ Koichiro Akasaka, ${ }^{\text {a }}$ Susumu \\ Saeki, ${ }^{a}$ Kenji Hisada, ${ }^{b}$ Tatsuhiro Goda ${ }^{a}$ and Youji Shimomura ${ }^{a}$ \\ ${ }^{a}$ Department of Materials Science and Engineering, Faculty of Engineering, University \\ of Fukui, Fukui, 910-8507, Japan E-mail: tokunaga@matse.fukui-u.ac.jp \\ ${ }^{\mathrm{b}}$ Department of Applied Chemistry and Biotechnology, Faculty of Engineering, \\ University of Fukui, Fukui, 910-8507, Japan
}

Keywords: Rotaxane; High pressure; Activation volume; Hydrogen bonding;

Corresponding author. Fax: +81-776-27-8611; e-mail: tokunaga@matse.fukui-u.ac.jp

\begin{abstract}
By using high-pressure conditions the formation of pseudorotaxane via the slipping approach is accelerated. Analysis of the effects of pressure on the rate constants affords activation volumes for the pseudorotaxane forming, slipping reactions.
\end{abstract}


Rotaxane synthesis remains a great challenge in supramolecular chemistry. ${ }^{1}$ The three main approaches used for rotaxane synthesis are the threading-stoppering, ${ }^{2}$ clipping, ${ }^{3}$ and slipping ${ }^{4}$ methods, and others have been devised. ${ }^{5,6,7}$ Among these strategies, the advantages of slipping method are that only thermal conditions are required, that other chemicals or reagents are not needed, and that by-products are not formed. Despite these advantages, only a few examples employing this technique have been reported. The major reason for this is that the stopper of the dumbbell-like axle and the cavity size of macrocycle must be designed to be rigorously complimentary, making synthesis of stable rotaxanes by this approach difficult.

High pressure reaction conditions have been used advantageously in the preparation of organic compounds that are difficult to synthesize at ambient pressures. ${ }^{8}$ In general, reactions in which the molecularity decreases in proceeding from reactants to products (e.g., cycloadditions and condensations) are facilitated by using high-pressures, since these processes have negative volumes of activation. Since molecularity decreases and bulky stopper part of the dumbbell-like axles must enter the cavity of hosts in the slipping synthesis of rotaxanes, it seems likely that the volumes of activation of theses processes would be negative. This proposal was tested by probing the effect of pressure on the rates of formation of pseudorotaxane, comprised of secondary ammonium ions and crown ethers, by the slipping method (Fig. 1). ${ }^{9}$ The results of this effort are presented below.

\section{Fig. 1}

Kinetic measurements were made initially by using a mixture of dibenzo[24]crown8 1a and bis(cyclohexylmethyl)ammonium salt 2a, a pair known to form the corresponding pseudorotaxane 3a slowly at ambient temperature and pressure (Fig. 2). ${ }^{10}$ The progress of the reaction of an equimolar (15 mM ) mixture of $\mathbf{1 a}$ and $\mathbf{2 a}$ in $\mathrm{CDCl}_{3}-\mathrm{CD}_{3} \mathrm{CN}$ was monitored by using ${ }^{1} \mathrm{H} \mathrm{NMR}$ spectroscopy. A plot of the reciprocal of the 1a concentration vs. time was linear at low conversions. ${ }^{11,12}$ As expected, this process shows typical second-order behaviour at conversions lower than $10 \%$. At this point, effects of the reverse reaction of pseudorotaxane 3a begin to contribute. Having obtained the rate constant $(k)$ for pseudorotaxane formation at $1 \mathrm{kgcm}^{-2}$, we next evaluated the effects of pressure on the rate of this process. Reactions, using equimolar mixtures (15 $\mathrm{mM}$ ) of 1a and 2a in $\mathrm{CDCl}_{3}-\mathrm{CD}_{3} \mathrm{CN}$ ) were carried out at $30{ }^{\circ} \mathrm{C}$ at pressures ranging from 1 to 5000 $\mathrm{kgcm}^{-2}$. In each case plots of $1 /[\mathbf{2 a}]$ vs. time at low conversion were linear and gave rise to second order rate constants $k{ }^{11}$ As expected, the rates of rotaxane formation increase as the pressure increases. For example the rate constant at $5000 \mathrm{kgcm}^{-2}\left(6.5 \times 10^{-4} \pm 0.5 \times 10^{-4} \mathrm{M}^{-1} \mathrm{~h}^{-1}\right)$ is more than 20 times larger than the value at $1 \mathrm{kgcm}^{-2}\left(3.3 \times 10^{-5} \pm 0.3 \times 10^{-5} \mathrm{M}^{-1} \mathrm{~h}^{-1}\right)$ (Fig. 3). Measurements of rate constants as a function of pressure, made on pseudorotaxane forming reactions carried out at 40 and $50{ }^{\circ} \mathrm{C}$, show that pressure increases accelerate the slipping reaction at higher temperatures also. ${ }^{13}$ 
Fig. 2.

Fig. 3.

Next, pressure effects on the rates of rotaxane formation between tetrabenzo[24]crown8 $\mathbf{1 b}$ and dibenzylammonium salt $\mathbf{2 b}$ were investigated. ${ }^{14}$ These processes were conducted using $10 \mathrm{mM}$ solutions (in $\mathrm{CDCl}_{3}-\mathrm{CD}_{3} \mathrm{CN}$ ) of each reactant at $30^{\circ} \mathrm{C}, 40{ }^{\circ} \mathrm{C}$, and $50{ }^{\circ} \mathrm{C}$ in pressure ranges up to $3000 \mathrm{kgcm}^{-2}$. Again, rate constants were obtained by determining the time dependence of formation of the pseudorotaxane $3 \mathbf{b} .^{13}$ The rate constants for this process are directly dependent on pressure at all temperatures $\left(k\left(30{ }^{\circ} \mathrm{C}\right)=1.3 \times 10^{-3} \pm 0.1 \times 10^{-3} \mathrm{M}^{-1} \mathrm{~h}^{-1}\right.$ at $3000 \mathrm{kgcm}^{-2}$ and $k\left(30{ }^{\circ} \mathrm{C}\right)=1.0 \times 10^{-4} \pm$ $0.2 \times 10^{-4} \mathrm{M}^{-1} \mathrm{~h}^{-1}$ at $\left.1 \mathrm{kgcm}^{-2}\right){ }^{15}$

The rate constant $v s$. pressure data permits an estimation of the activation volumes $\left(V^{\ddagger}=\right.$ $\left.-R T(\partial \ln k / \partial P)_{\mathrm{T}}\right)$ for the rotaxane forming reactions. Plots of lnk vs. $P$ give curved lines (Fig. 4 ) like those typically seen in the analysis of other high pressure-promoted reactions (e.g., Diels-Alder reaction). Others have discussed how the curvature of these plots, which normally indicates that the activation volumes are not independent of pressure, complicates the accurate determination of volumes of activation difficult. A suggested solution to this problem, involving the use of the quadratic equation, $\ln k=a P^{2}+b P+c,{ }^{8}$ was employed to estimate the volumes of activation for the respective $\mathbf{1 a}+\mathbf{2 a}$ and $\mathbf{1} \mathbf{b}+\mathbf{2} \mathbf{b}$ reactions to be -2.6 to $-5.7 \mathrm{~cm}^{3} \mathrm{~mol}^{-1}$. Although not as strongly negative as those for Diels-Alder reactions, these volumes of activation indicate that pressure can have a beneficial effect on slipping reactions used for rotaxane synthesis (Table 1).

Fig. 4.

Table 1.

Since slipping reactions are not associated with any bond cleaving and forming processes, their negative volumes of activation result from fitting the stopper end of ammonium groups into the cavity of crown in rate limiting transition states. This result suggests that free volumes in crown cavities decrease in proceeding from the reactants to the transition states for rotaxane formation as a result of the complimentary sizes of cavities and stopper ends (Fig. 5). Recently, three-dimensional structures of transition states of the slipping process were investigated by use of computational methods. ${ }^{16}$ The calculated results are in good agreement with their experimental observations. The activation volumes determined in the current effort could provide a more quantitative explanation for the rigorous requirement of size complementarily in rotaxane forming, slipping reactions.

Fig. 5 
In summary, the observations described above show that high pressures accelerate rotaxane formation by the slipping approach. Like the recently reported solventless reaction technique, ${ }^{17}$ the high-pressure methodology, which leads to dramatic rate enhancements, should be applicable to a number of processes used for supramolecular self-assembly.

\section{Acknowledgements}

We thank Professor Uchida of this University for profitable comments. This work was supported by Innovation plaza Ishikawa of JST (Japan Science and Technology Agency) and a Grant-in-Aid for Scientific Research on Encouraged Areas (No. 15750116) from Ministry of Education, Culture, Sports, Science, and Technology, Japan.

\section{Supplementary data}

Plots of 1/[2] vs. time for reactions of equimolar mixtures of 1a with $2 \mathbf{2 a}$ (40 and $50{ }^{\circ} \mathrm{C}$, $\left.\mathrm{CDCl}_{3}-\mathrm{CD}_{3} \mathrm{CN}\right)$ and of $\mathbf{1 b}$ with $\mathbf{2 b}\left(30,40\right.$, and $\left.50{ }^{\circ} \mathrm{C}, \mathrm{CDCl}_{3}-\mathrm{CD}_{3} \mathrm{CN}\right)$ at various pressures.

\section{References and notes}

1. (a) Balzai, V.; Credi, A.; Raymo, F. M.; Stoddart, J. F. Angew. Chem., Int. Ed. 2000, 39, 3348-3391; (b) Ballardini, R.; Balzani, V.; Credi, A.; Gandolfi, M. T.; Venturi, M. Acc. Chem. Res. 2001, 34, 445-455; (c) Harada, A. Acc. Chem. Res. 2001, 34, 456-464; (d) Schalley, C. A.; Beizai, K.; Vögtle, F. Acc. Chem. Res. 2001, 34, 465-476; (e) Collin, J.-P.; Dietrich-Buchecker, C.; Gavina, P.; Jimenez-Molero, M. C.; Sauvage, J.-P. Acc. Chem. Res. 2001, 34, 477-487.

2. (a) Cao, J.; Fyfe, M. C. T.; Stoddart, J. F.; Cousins, G. R. L.; Glink, P. T. J. Org. Chem. 2000, 65, 1937-1946; (b) Watanabe, N.; Yagi, T.; Kihara, N.; Takata, T. Chem. Commun. 2002, 2720-2721; (c) Cantrill, S. J.; Fulton, D. A.; Heiss, A. M.; Pease, A. R.; Stoddart, J. F.; White, A. J. P.; Williams, D. J. Chem. Eur. J. 2000, 6, 2274-2287; (d) Kolchinski, A. G.; Alcock, N. W.; Roesner, R. A.; Busch, D. H. Chem. Commun. 1998, 1437-1438; (e) Tokunaga, Y.; Kakuchi, S.; Akasaka, K.; Nishikawa, N.; Shimomura, Y.; Isa, K.; Seo, T. Chem. Lett. 2002, 810-811; (f) Zehnder II, D. W.; Smithrud, D. B. Org. Lett. 2001, 3, 2485-2487; (G) Hung, W.-C.; Liao, K.-S.; Liu, Y.-H.; Peng, S.-M.; Chiu, S.-H. Org. Lett. 2004, 6, 4183-4186.

3. (a) Asakawa, M.; Brancato, G.; Fanti, M.; Leigh, D. A.; Shimizu, T.; Slawin, A. M. Z.; Wong, J. K. Y.; Zerbetto, F.; Zhang, S. J. Am. Chem. Soc. 2002, 124, 2939-2950; (b) Wisner, J. A.; Beer, P. D.; Drew, M. G. B.; Sambrook, M. R. J. Am. Chem. Soc. 2002, 124, 12469-12476; (c) Glink, 
P. T.; Oliva, A. I.; Stoddart, J. F.; White, A. J. P.; Williams, D. J. Angew. Chem., Int. Ed. 2001, 40, 1870-1875.

4. (a) Cantrill, S. J.; Preece, J. A.; Stoddart, J. F.; Wang, Z.-H.; White, A. J. P.; Williams, D. J. Tetrahedron 2000, 56, 6675-6681; (b) Händel, M.; Plevoets, M.; Gestermann, S.; Vögtle, F. Angew. Chem., Int. Ed. 1997, 36, 1199-1201.

5. Yoon, I.; Narita, M.; Shimizu, T.; Asakawa, M. J. Am. Chem. Soc. 2004, 126, 16740-16741.

6. Kameta, N.; Hiratani, K.; Nagawa, Y. Chem. Commun. 2004, 466-467.

7. Tokunaga, Y.; Akasaka, K.; Hisada, K.; Shimomura, Y.; Kakuchi, S. Chem. Commun. 2003, 2250-2251.

8. For reviews on high-pressure synthesis of organic compounds, see: (a) van Eldik, R.; Asano, T.; le Noble, W. J. Chem. Rev. 1989, 89, 549-688; (b) Drljaca, A.; Hubbard, C. D.; van Eldik, R.; Asano, T.; Basilevsky, M. V.; le Noble, W. J. Chem. Rev. 1998, 98, 2167-2289; (c) Matsumoto, K.; Sera, A.; Uchida, T. Synthesis 1985, 1-26; (d) Matsumoto, K.; Sera, A. Synthesis 1985, 999-1027; (e) le Noble, W. J.; Kelm, H. Angew. Chem., Int. Ed. 1980, 19, 841-856; (f) Jenner, G. J. Chem. Soc., Farady Trans 1 1985, 81, 2437-2460; (g) Isaacs, N. S. Tetrahedron 1991, 47, 8463-8497; (h) Jenner, G. Tetrahedron 2005, 61, 3621-3635.

9. The clipping synthesis of rotaxane was employed under ultra-high-pressure, but the effect of pressure was not discussed. For example; Jeppesen, J. O.; Nielsen, K. A.; Perkins, J.; Vignon, S. A.; Fabio, A. D.; Ballardini, R.; Gandolfi, M. T.; Venturi, M.; Balzani, V.; Becher, J.; Stoddart, J. F. Chem. Eur. J., 2003, 9, 2982-3007.

10. Ashton, P. R.; Baxter, I.; Fyfe, M. C. T.; Raymo, F. M.; Spencer, N.; Stoddart, J. F.; White, A. J. P.; Williams, D. J. J. Am. Chem. Soc. 1998, 120, 2297- 2307. The reaction rate is preferable to monitoer both species.

11. When the formation of ion-pairs was not considered, the second-order rate equation would be

$$
\begin{aligned}
& -\mathrm{d}[\mathbf{1}] / \mathrm{d} t=-\mathrm{d}[2] / \mathrm{d} t=k[\mathbf{1}][2] \quad \text { In the case of }[\mathbf{1}]=[2] \\
& 1 /[2]=k t+1 /[2]_{0}
\end{aligned}
$$

12. The association constant between ammonium salts and ammonium ions using ammonium-crown system in $\mathrm{CDCl}_{3} / \mathrm{CD}_{3} \mathrm{CN}$ was reported by Gibson's group. In consideration of their results, ca $70 \%$ of ammonium existed as an ion during our reactions at $1 \mathrm{kgcm}^{-2}$. Even though high-pressure condition accelerates the dissociation of ion pairing, the promotion of the slipping is less than 1.4 times; see: Jones, J. W.; Gibson, H. W. J. Am. Chem. Soc. 2003, 125, 7001 -7004 .

13. See electronic supplementary data.

14. Since TB24C 8 has a delicately smaller cavity size, the association rate of $\mathbf{1 b}$ and $\mathbf{2} \mathbf{b}$ is favorable to monitor; see; Tokunaga,Y.; Goda, T.; Wakamatsu, N.; Nakata, R.; Shimomura, Y. Heterocycles, 2006, 68, 5-10. 
15. The thermal reaction of both reactants $\left(50{ }^{\circ} \mathrm{C}, 1 \mathrm{~atm}, 28\right.$ days) afforded $3 \mathbf{b}$ in $58 \%$ conversion yield. In contrast, the high-pressure conditions $\left(50{ }^{\circ} \mathrm{C}, 2500 \mathrm{~atm}, 17\right.$ days $)$ gave $3 \mathbf{b}$ in $66 \%$ conversion yield.

16. Raymo, F. M.; Houk, K. N.; Stoddart, J. F. J. Am. Chem. Soc. 1998, 120, 9318-9322.

17. Orita, A.; Okano, J.; Tawa, Y.; Jiang, L.; Otera, J. Angew. Chem., Int. Ed. 2004, 43, 3724-3728. 


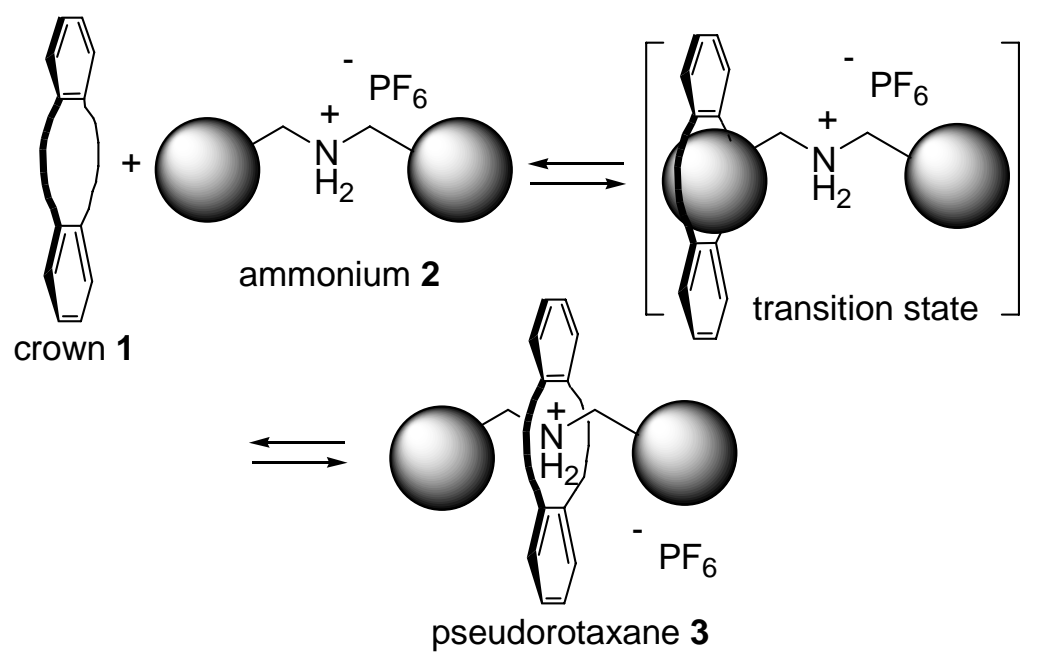

Figure 1. An illustration of the slipping approach for rotaxane synthesis. 
<smiles>CCOc1ccccc1OCCOc1ccccc1OCCOc1ccccc1OCCOc1ccccc1OCCOc1ccccc1OCCOc1ccccc1</smiles>

1a: DB24C8

1b: TB24C8

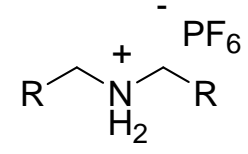

2a: $\mathrm{R}=\mathrm{C}_{6} \mathrm{H}_{11}$

2b: $\mathrm{R}=\mathrm{C}_{6} \mathrm{H}_{5}$

Figure 2. Structures of crowns $\mathbf{1}$ and ammonium salts 2. 


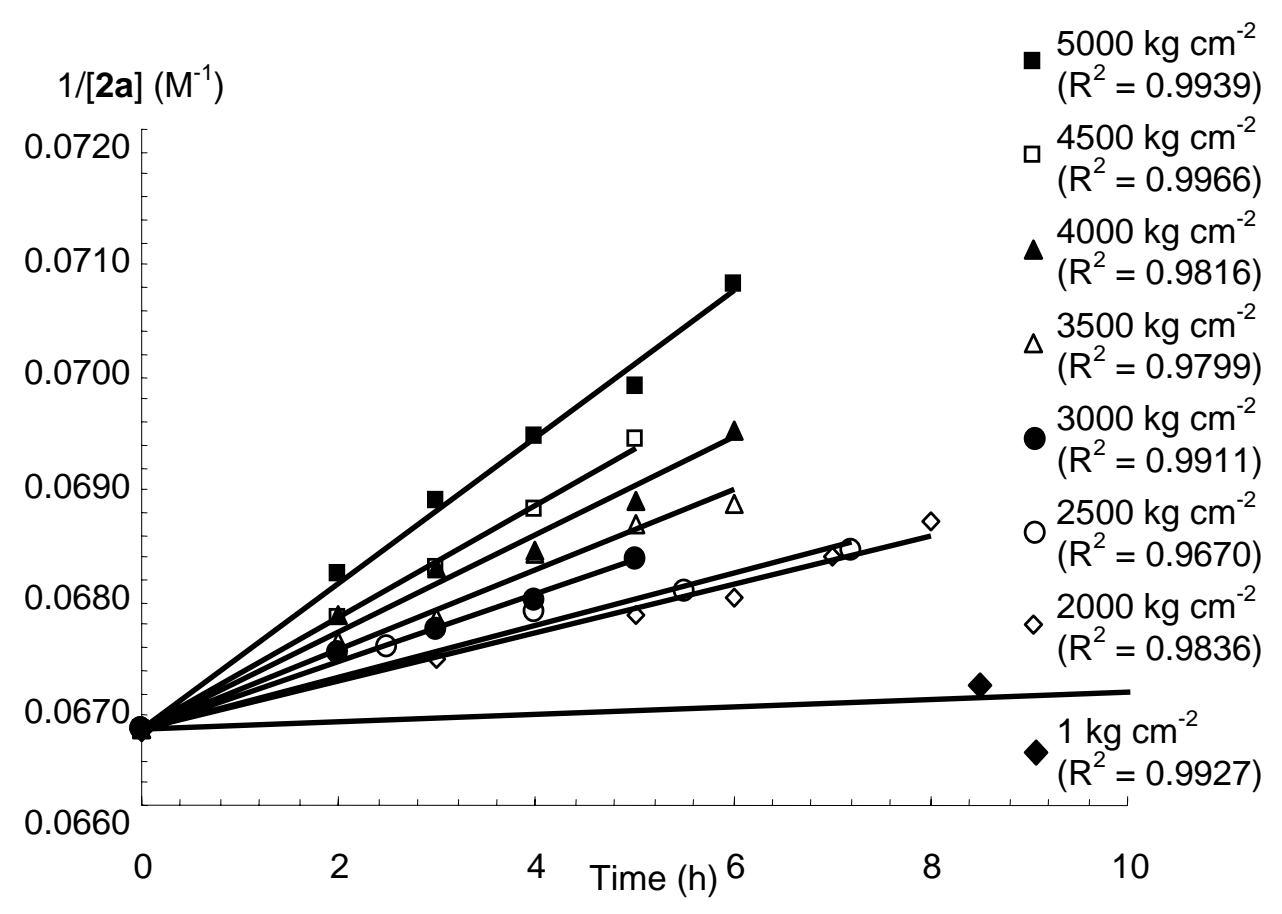

Figure 3. Plots of $1 /[2 \mathbf{a}]$ vs. time for reaction of equimolar $(15 \mathrm{mM})$ mixtures of $\mathbf{1 a}$ with $\mathbf{2 a}\left(30^{\circ} \mathrm{C}\right.$, $\mathrm{CDCl}_{3}-\mathrm{CD}_{3} \mathrm{CN}$ ) at various pressures. 


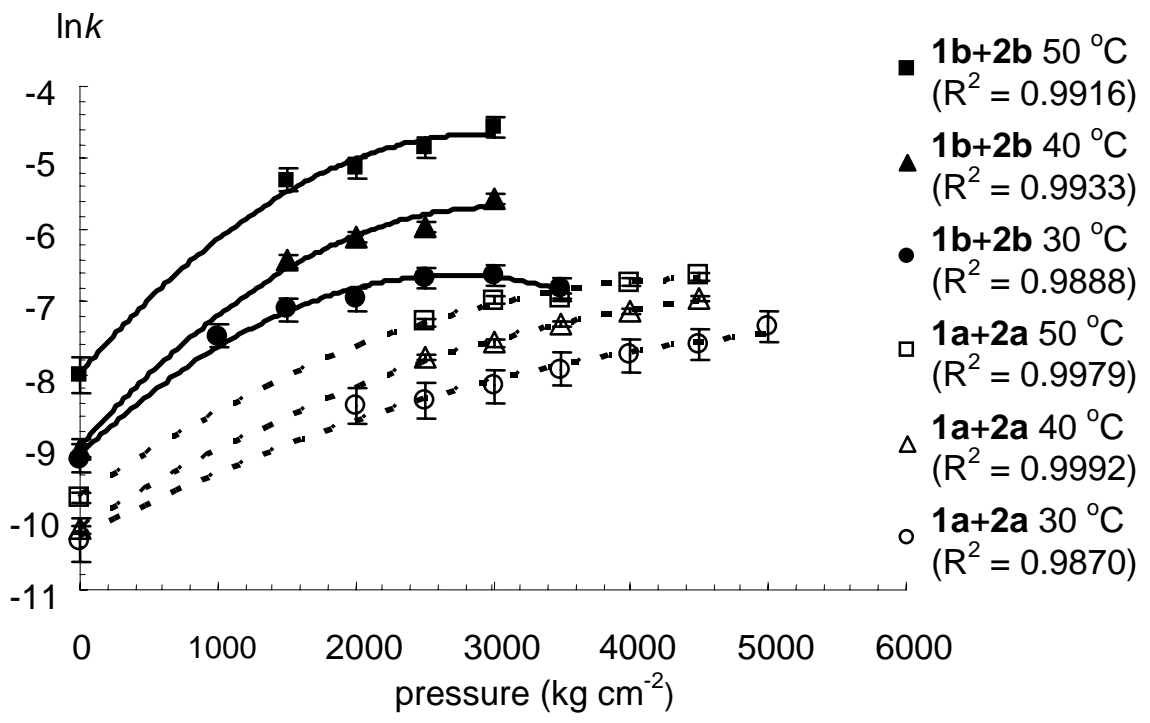

Figure 4. Plots of lnk vs. pressure for reactions of $1 \mathbf{a}$ with $2 \mathbf{a}\left(15 \mathrm{mM}, 30^{\circ} \mathrm{C}, \mathrm{CDCl}_{3}-\mathrm{CD}_{3} \mathrm{CN}\right)$ and of 1b with $2 \mathbf{b}\left(10 \mathrm{mM}, 30^{\circ} \mathrm{C}, \mathrm{CDCl}_{3}-\mathrm{CD}_{3} \mathrm{CN}\right)$. 


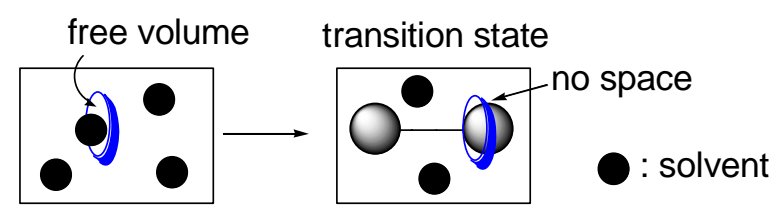

Figure 5. A pictorial representation of rotaxane forming, slipping processes. 
Table 1. The activation volumes of the pseudorotaxane formation at $1 \mathrm{~kg} \mathrm{~cm}^{-2}$.

\begin{tabular}{lll} 
& $\mathbf{1 a - 2 a}$ & $\mathbf{1 b}-\mathbf{2 b}$ \\
\hline $30{ }^{\circ} \mathrm{C}$ & -2.6 & -4.9 \\
$40^{\circ} \mathrm{C}$ & -3.1 & -5.7 \\
$50^{\circ} \mathrm{C}$ & -3.4 & -5.7 \\
\hline
\end{tabular}

${ }^{\mathrm{a}} \mathrm{cm}^{3} \mathrm{~mol}^{-1}$. 


\section{-Supplementary Data-}

Kinetics of pseudorotaxane formation

1a-2a at $40^{\circ} \mathrm{C}$

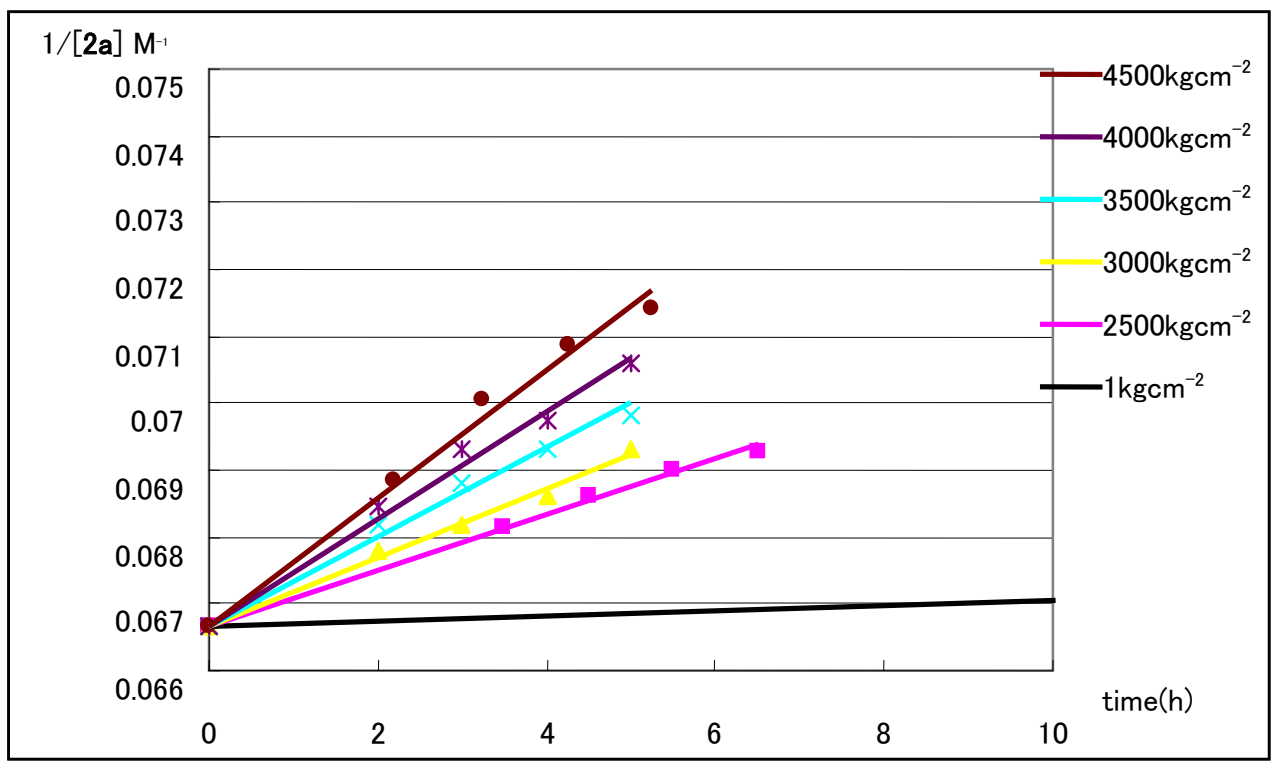

1a-2a at $50^{\circ} \mathrm{C}$

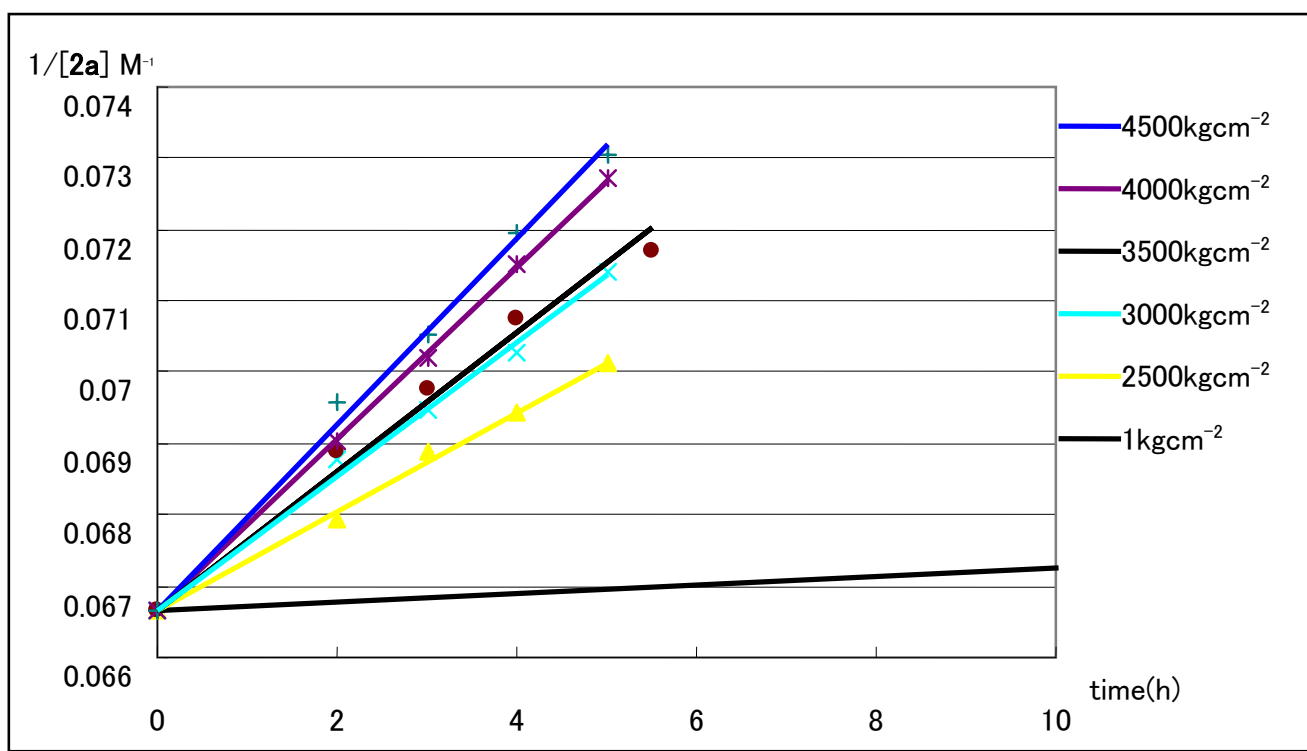


1b-2b at $30^{\circ} \mathrm{C}$

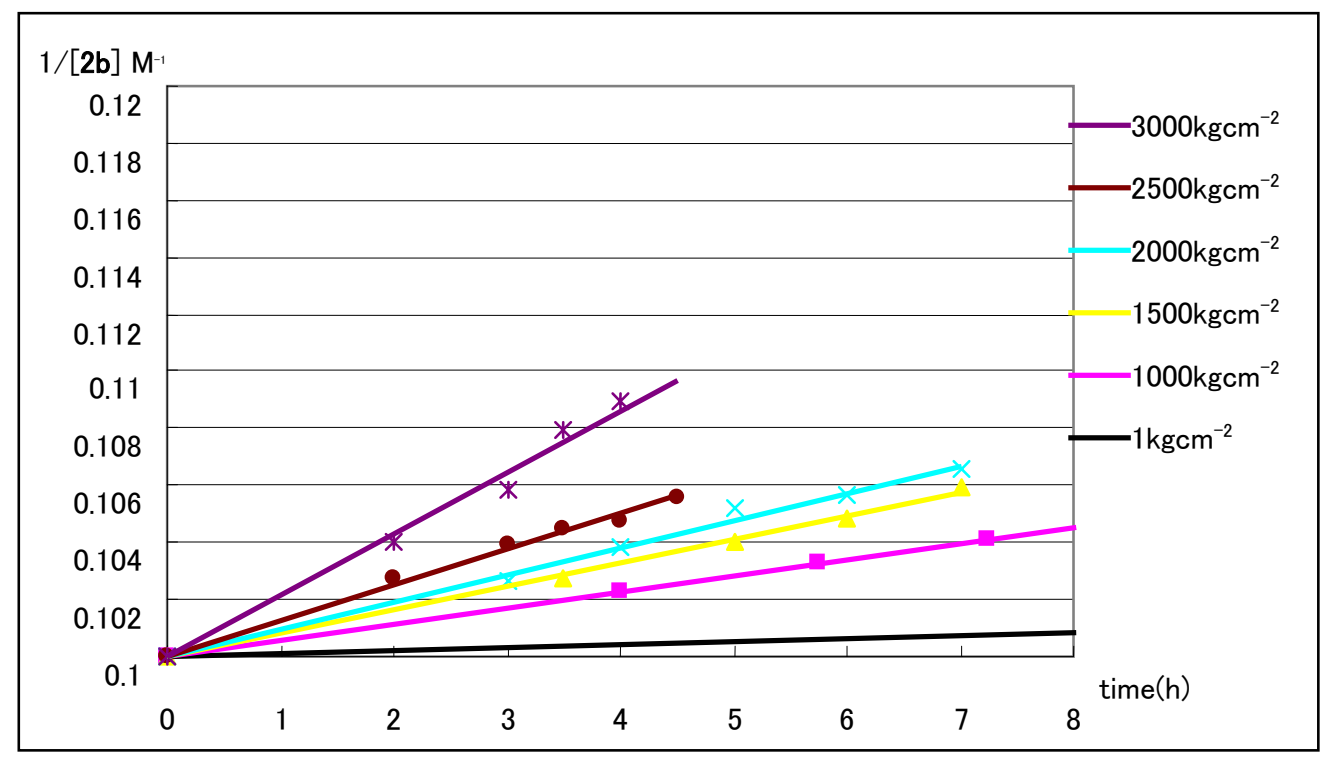

1b-2b at $40^{\circ} \mathrm{C}$

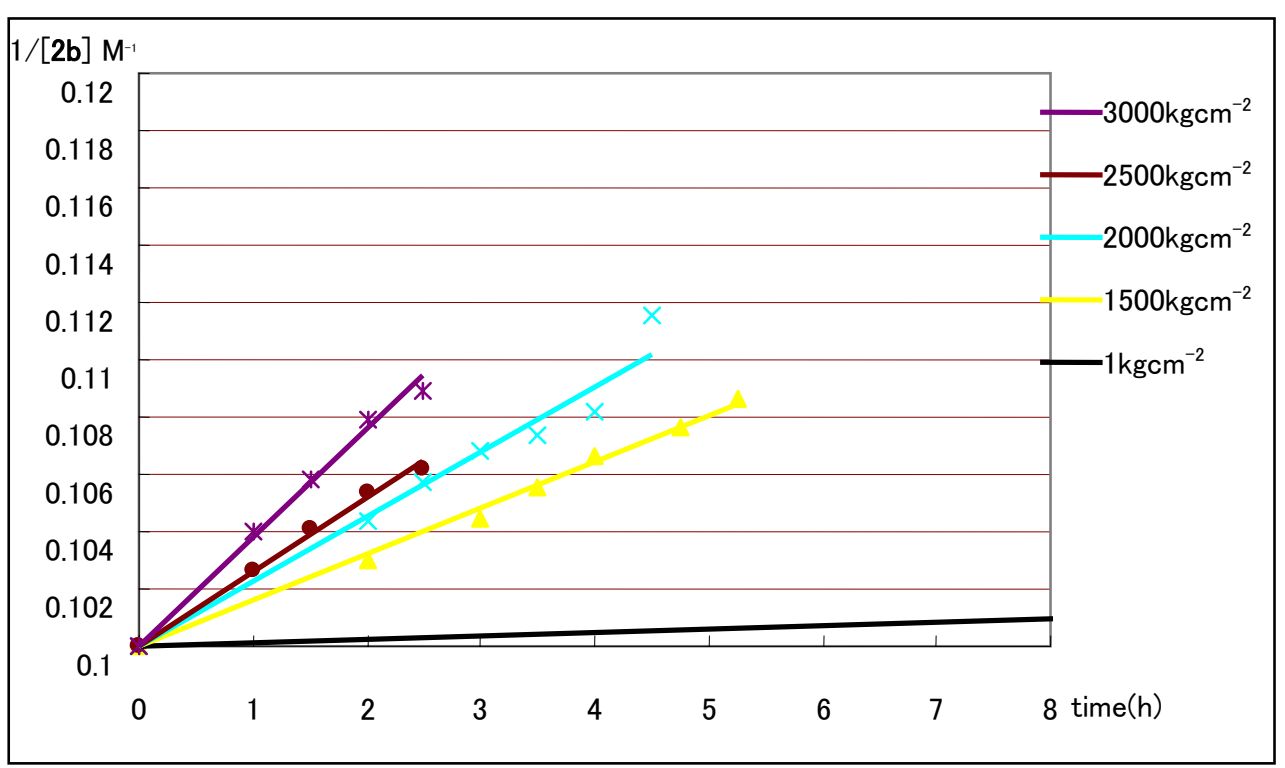


1b-2b at $50^{\circ} \mathrm{C}$

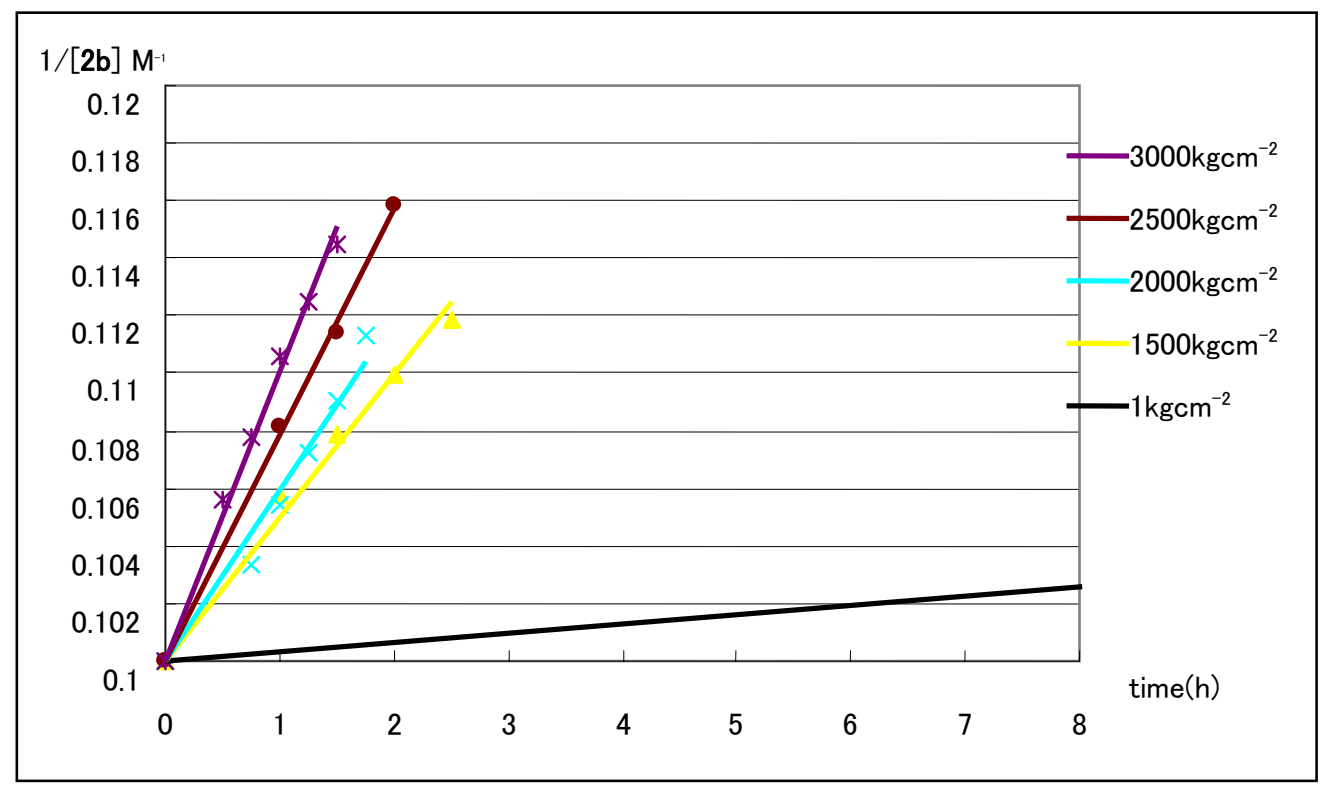


Table. The reaction constant $\left(\mathrm{M}^{-1} \mathrm{~h}^{-1}\right)$ of reactions between $\mathbf{1}$ and $\mathbf{2}$.

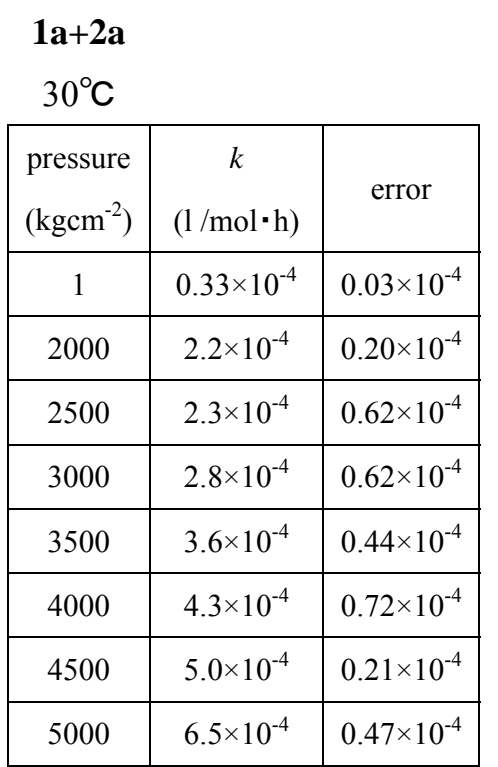

\begin{tabular}{l}
$40{ }^{\circ} \mathrm{C}$ \\
\begin{tabular}{|c|c|c|}
\hline $\begin{array}{c}\text { pressure } \\
\left(\mathrm{kgcm}^{-2}\right)\end{array}$ & $\begin{array}{c}k \\
(1 / \mathrm{mol} \cdot \mathrm{h})\end{array}$ & error \\
\hline 1 & $0.39 \times 10^{-4}$ & $0.02 \times 10^{-4}$ \\
\hline & & \\
\hline 2500 & $4.2 \times 10^{-4}$ & $0.52 \times 10^{-4}$ \\
\hline 3000 & $5.2 \times 10^{-4}$ & $0.52 \times 10^{-4}$ \\
\hline 3500 & $6.7 \times 10^{-4}$ & $1.01 \times 10^{-4}$ \\
\hline 4000 & $8.1 \times 10^{-4}$ & $0.91 \times 10^{-4}$ \\
\hline 4500 & $9.6 \times 10^{-4}$ & $0.77 \times 10^{-4}$ \\
\hline
\end{tabular} \\
\hline
\end{tabular}

\begin{tabular}{|c|c|c|}
\hline $\begin{array}{l}\text { pressure } \\
\left(\mathrm{kgcm}^{-2}\right)\end{array}$ & $\begin{array}{c}k \\
(1 / \mathrm{mol} \cdot \mathrm{h})\end{array}$ & error \\
\hline 1 & $0.60 \times 10^{-4}$ & $0.05 \times 10^{-4}$ \\
\hline 2500 & $7.0 \times 10^{-4}$ & $0.55 \times 10^{-4}$ \\
\hline 3000 & $9.4 \times 10^{-4}$ & $1.10 \times 10^{-4}$ \\
\hline 3500 & $9.7 \times 10^{-4}$ & $1.30 \times 10^{-4}$ \\
\hline 4000 & $12 \times 10^{-4}$ & $0.32 \times 10^{-4}$ \\
\hline 4500 & $13 \times 10^{-4}$ & $1.56 \times 10^{-4}$ \\
\hline
\end{tabular}

\section{$1 b+2 b$}

\begin{tabular}{|c|c|c|}
\hline $\begin{array}{l}\text { pressure } \\
\left(\mathrm{kgcm}^{-2}\right)\end{array}$ & $\begin{array}{c}k \\
(1 / \mathrm{mol} \cdot \mathrm{h})\end{array}$ & error \\
\hline 1 & $1.0 \times 10^{-4}$ & $0.23 \times 10^{-4}$ \\
\hline 1000 & $5.7 \times 10^{-4}$ & $0.05 \times 10^{-4}$ \\
\hline 1500 & $8.2 \times 10^{-4}$ & $0.35 \times 10^{-4}$ \\
\hline 2000 & $9.5 \times 10^{-4}$ & $0.82 \times 10^{-4}$ \\
\hline 2500 & $1.3 \times 10^{-3}$ & $0.09 \times 10^{-3}$ \\
\hline 3000 & $1.3 \times 10^{-3}$ & $0.17 \times 10^{-3}$ \\
\hline 3500 & $1.1 \times 10^{-3}$ & $0.10 \times 10^{-3}$ \\
\hline
\end{tabular}

$40^{\circ} \mathrm{C}$
\begin{tabular}{|c|c|c|}
\hline $\begin{array}{c}\text { pressure } \\
\left(\mathrm{kgcm}^{-2}\right)\end{array}$ & $\begin{array}{c}k \\
(1 / \mathrm{mol} \cdot \mathrm{h})\end{array}$ & error \\
\hline 1 & $0.12 \times 10^{-3}$ & $0.02 \times 10^{-3}$ \\
\hline & & \\
\hline 1500 & $1.6 \times 10^{-3}$ & $0.13 \times 10^{-3}$ \\
\hline 2000 & $2.3 \times 10^{-3}$ & $0.16 \times 10^{-3}$ \\
\hline 2500 & $2.6 \times 10^{-3}$ & $0.16 \times 10^{-3}$ \\
\hline 3000 & $3.8 \times 10^{-3}$ & $0.25 \times 10^{-3}$ \\
\hline
\end{tabular}

$50^{\circ} \mathrm{C}$
\begin{tabular}{|c|c|c|}
\hline $\begin{array}{c}\text { pressure } \\
\left(\mathrm{kgcm}^{-2}\right)\end{array}$ & $\begin{array}{c}k \\
(1 / \mathrm{mol} \cdot \mathrm{h})\end{array}$ & error \\
\hline 1 & $0.33 \times 10^{-3}$ & $0.08 \times 10^{-3}$ \\
\hline & & \\
\hline 1500 & $5.0 \times 10^{-3}$ & $0.81 \times 10^{-3}$ \\
\hline 2000 & $5.9 \times 10^{-3}$ & $1.50 \times 10^{-3}$ \\
\hline 2500 & $7.8 \times 10^{-3}$ & $0.29 \times 10^{-3}$ \\
\hline 3000 & $10 \times 10^{-3}$ & $0.97 \times 10^{-3}$ \\
\hline
\end{tabular}

